\title{
Article \\ Inhibition of Human Monoamine Oxidases A and B by Specialized Metabolites Present in Fresh Common Fruits and Vegetables
}

\author{
Claudio Marcello Marzo *,+(D), Sofia Gambini ${ }^{+}(\mathbb{D}$, Stefania Poletti, Francesca Munari, Michael Assfalg \\ and Flavia Guzzo*
}

check for

updates

Citation: Marzo, C.M.; Gambini, S.;

Poletti, S.; Munari, F.; Assfalg, M.;

Guzzo, F. Inhibition of Human

Monoamine Oxidases A and B by

Specialized Metabolites Present in

Fresh Common Fruits and Vegetables.

Plants 2022, 11, 346. https://doi.org/ $10.3390 /$ plants 11030346

Academic Editors: Filippo Maggi and Daniela Rigano

Received: 28 October 2021

Accepted: 21 January 2022

Published: 27 January 2022

Publisher's Note: MDPI stays neutral with regard to jurisdictional claims in published maps and institutional affiliations.

Copyright: (c) 2022 by the authors. Licensee MDPI, Basel, Switzerland. This article is an open access article distributed under the terms and conditions of the Creative Commons Attribution (CC BY) license (https:// creativecommons.org/licenses/by/ $4.0 /)$.
Department of Biotechnology, University of Verona, Strada Le Grazie 15, 37134 Verona, Italy; sofia.gambini@univr.it (S.G.); stefania.poletti@univr.it (S.P.); francesca.munari@univr.it (F.M.); michael.assfalg@univr.it (M.A.)

* Correspondence: claudiomarcello.marzo@univr.it (C.M.M.); flavia.guzzo@univr.it (F.G.)

+ These authors contributed equally to this work.

\begin{abstract}
Diets rich in fruits and vegetables are associated with better psychological wellbeing and cognitive functions, although it is unclear which molecules and mechanisms are involved. One potential explanation is the inhibition of monoamine oxidases (MAOs), which have been linked to several neurological disorders. The present study investigated the ability of kiwifruit to inhibit MAO$\mathrm{A}$ and MAO-B, refining an in vitro assay to avoid confounding effects. Ultra-performance liquid chromatography/mass spectrometry (UPLC-QTOF) and nuclear magnetic resonance spectroscopy (NMR) were used to select individual kiwifruit metabolites for further analysis. Moreover, extracts of other common fruits and vegetables were screened to identify promising candidate inhibitors. Multiple extracts and compounds inhibited both enzymes, and the selective inhibition of MAO-B by the major kiwifruit specialized metabolite D-(-)-quinic acid was observed. These results suggest that fruits and vegetables contain metabolites that inhibit the activity of MAO-A and - B, offering a potential natural option for the treatment of neurological disorders, in which MAOs are involved.
\end{abstract}

Keywords: monoamine oxidase; phenylpropanoid; D-(-)-Quinic acid; untargeted metabolomics; kiwifruit; polyphenols

\section{Introduction}

The beneficial effects of a diet rich in fruits, vegetables, nuts, and vegetable-based ingredients are widely recognized, particularly in the context of cardiovascular disease [1]. More recent studies have linked such diets to mental health, including observational and small intervention studies focusing on the benefits of a so-called Mediterranean diet. These reports revealed a positive impact on cognitive performance [2], depression [3], and psychological wellbeing [4,5]. Randomized controlled registered trials have also produced promising results [6]. Observational and interventional studies on the effect of whole dietetic patterns on brain health, while being powerful tools, cannot determine which fruits and vegetables (and which molecules) are responsible for the positive effects. This would require interventional studies with a single fruit or vegetable, which have been carried out, just to give some examples, with gold kiwifruit [7], orange juice [8], and sour cherry [9]. Kiwifruit (Actinidia deliciosa) and gold kiwifruit (Actinidia chinensis) are of particular interest, as they have shown antidepressant activity in humans and animals $[7,10]$.

Studies have involved in vitro tests, which can identify molecular targets but cannot provide information about efficacy at the organism level, as well as in vivo tests in animal models and humans, which can demonstrate efficacy at the organism level but generally cannot identify molecular targets. One potential link between fruits and vegetables in diet and brain health is the ability of certain metabolites to inhibit the enzymes monoamine oxidase 
(MAO) [11]. This flavin-containing enzyme (EC 1.4.3.4) catalyzes the oxidative deamination of primary and some secondary amines, including the catecholamines, serotonin, and trace amines. Humans possess two isozymes of $\mathrm{MAO}$, named $\mathrm{MAO}-\mathrm{A}$ and $-\mathrm{B}$, both located on the outer membrane of mitochondria [11]. The isozymes were originally defined according to differences in substrate and inhibitor sensitivity: MAO-A has a higher affinity for serotonin and norepinephrine and is sensitive to low concentrations of clorgyline, whereas MAO-B prefers $\beta$-phenethylamine as a substrate and is inhibited by low concentrations of deprenyl (selegiline) [12]. MAO-A is predominantly expressed in the placenta, intestine, liver, and lungs, whereas MAO-B is the prevalent form in platelets [13]; both appear to play a protective role by catalyzing the oxidative deamination of biogenic and xenobiotic amines [14]. In the brain, MAO-A is predominantly found in catecholaminergic neurons, whereas MAO-B is more abundant in serotonergic and histaminergic neurons, especially in glial cells [15]. In addition, there are some differences in the distribution of MAOs through rodents and humans, indeed there are more type A than type B enzymes throughout the rat brain; whereas, in the human brain, it is the opposite. Serotonergic neurons, therefore, contain the form of MAO that does not preferentially metabolize 5-hydroxytryptamine [11].

Given the role of MAOs in the metabolism of neuroactive amines, monoamine oxidases inhibitors (MAOIs) have been used extensively in clinical states, such as depression, with the aim to increase dysregulated monoamine levels. Nowadays, MAO-A inhibitors have limited therapeutic use, due to potentially dangerous side effects or drug interactions, while MAO-B inhibitors are still in use as an adjunct therapy in Parkinson's disease to elevate dopamine levels; there is great interest in the development of alternatives, including natural ones [11].

Numerous plant extracts have been tested for their ability to inhibit MAO, including a large-scale screen that identified five herbs used in traditional medicines, with a higher ability to inhibit MAO-B [16]. The analysis of numerous foods and herbal remedies has revealed a large number of plant metabolites with the ability to inhibit one or both isoforms of MAO [17]. One example is the flavonol quercetin, which inhibits both forms of MAO but shows greater activity against MAO-A [18], as supported by molecular docking studies [19]. Other flavonoids preferentially inhibit MAO-B, such as (+)-catechin, (-)-epicatechin and naringenin [20,21], whereas kaempferol and apigenin are more potent inhibitors of MAO-A [22]. Many investigators have focused on $\beta$-carbolines, which are bioactive alkaloids found in hallucinogenic plants, tobacco, and coffee [23]. For example, harman is a selective inhibitor of MAO-A, whereas norharman strongly inhibits both forms of the enzyme [24]. The alkaloid piperine and its related compounds, found in long pepper plants (Piper longum), are more potent inhibitors of MAO-B [25]. Anthocyanins, the abundant red and blue pigments found in plants such as cherry and red chicory, can also inhibit MAO, although their rarer aglycosylated counterparts (anthocyanidins) are more potent [26].

In this work, the setup of the MAO inhibition assay was initially performed on kiwifruit, both because of the interesting biological activities it has already demonstrated [10] and because it shares, with other fleshy fruits and vegetables, some features that can potentially interfere with the assay (such as acidic $\mathrm{pH}$, presence of various organic acids, and, for fruits, a very high concentration of sugars) [16]. Thus, we used it as the model fruit. High-resolution techniques (UPLC-MS and NMR) were used to select individual kiwifruit metabolites for assessing their effects on MAO-A and -B. Other juices, namely sweet cherry, apple, nectarine, peach, pear, carrot, fennel, cucumber, lettuce, tomato, red chicory, bell pepper, onion, and shallot, were subsequently screened to evaluate their inhibition activity on MAOs.

The results presented in this study demonstrate the ability of the juices of common fruits and vegetables to reduce MAOs activity in vitro suggesting, if data were replicated in vivo, a possible application as a supplementation tool in the treatment of various neurodegenerative disorders. 


\section{Materials and Methods}

\subsection{Reagents}

Clorgyline, R-(-)-deprenyl, human enzymes MAO-A and -B, expressed in baculovirusinfected insect cells (BTI-TN-5B1-4), caffeic acid, (+)-catechin hydrate, Bradford reagent, and bovine serum albumin (BSA), were obtained from MilliporeSigma (Milan, Italy). D(-)-quinic acid was purchased from Santa Cruz Biotechnology (Heidelberg, Germany). Esculin was obtained from Extrasynthese (Genay, France).

\subsection{Fruit and Vegetables Sampling}

A total of 18 different fruit and vegetable samples were tested, namely apple (Malus domestica) cv. golden delicious and cv. prussian, bell pepper (Capsicum annuum, ripe and unripe samples), carrot (Daucus carota), sweet cherry (Prunus avium) cv. black star and cv. roana, cucumber (Cucumis sativus), fennel (Foeniculum vulgare), kiwifruit (Actinidia deliciosa cv. hayward), lettuce (Lactuca sativa), nectarine (Prunus persica var. nectarina), onion (Allium cepa), peach (Prunus persica), pear (Pyrus communis), red chicory (Cichorium intybus), shallot (Allium ascalonicum), and tomato (Solanum lycopersicum). The two different cultivars of apple and sweet cherry were sampled directly in orchards, located in the Veneto Region of Italy; kiwifruits were sourced from local producers, and the other material was bought at the local market in Verona (Italy). To obtain juices with a representative composition, pools of 50 fruits, bulbs (onion and shallot), leaf heads (red chicory and lettuce), or fleshy shoot (fennel) were prepared by cutting slices of each sample, freezing them immediately in liquid nitrogen, and storing them at $-80^{\circ} \mathrm{C}$. The frozen material was powdered using an A11 basic analytical mill (IKA-Werke, Staufen, Germany), and the powder was stored at $-80^{\circ} \mathrm{C}$.

\subsection{Fresh Juice Preparation}

Each fresh juice was prepared by weighing and thawing $15 \mathrm{~g}$ of frozen homogenized powder and centrifuging at $3650 \times g$ for $15 \mathrm{~min}$ at $4{ }^{\circ} \mathrm{C}$. The supernatant was then transferred to a fresh tube and centrifuged at $21,000 \times \mathrm{g}$ for $15 \mathrm{~min}$ at $4{ }^{\circ} \mathrm{C}$. The supernatant was passed through a 0.22- $\mu \mathrm{m}$ Millex PES filter (MilliporeSigma, Milan, Italy) and the $\mathrm{pH}$ was adjusted to 7.5 with $\mathrm{NaOH}$. For kiwifruit experiments, in order to investigate molecules responsible for the activity on MAOs and limit the number of candidate inhibitors, the fresh juice was passed over a cation exchange cartridge to remove small, polar metabolites. This "neutralized juice" was created by passing the fresh kiwifruit juice through a Discovery DSC-MCAX SPE C8 mixed-mode cation exchange cartridge (MilliporeSigma, Milan, Italy), according to the manufacturer's instructions, with some minor modifications. Briefly, columns were activated with $15 \mathrm{~mL}$ of ethanol for $15 \mathrm{~min}$, then equilibrated with $25 \mathrm{~mL}$ of an acid aqueous solution with $1 \mathrm{mM}$ of malic acid ( $\mathrm{pH} 3.3$ ) and, finally, samples were loaded. In addition, five "vehicle" solutions were prepared containing the bulk components of fruit juice (various organic acids and/or sugars) (see Results 3.1).

\subsection{MAO-Glo Assay}

The ability of each sample to inhibit MAO in vitro was evaluated in 96-well flat bottom white opaque plates (Thermo Fisher Scientific, Rodano, Italy), using the two-step bioluminescent MAO-Glo assay (Promega, Milan, Italy), following the manufacturer's instructions. The reaction buffer comprised of $100 \mathrm{mM}$ HEPES $(\mathrm{pH} \mathrm{7.5)}$ and 5\% (v/v) glycerol for MAO-A, as well as 10\% $(v / v)$ dimethyl sulfoxide (DMSO) for MAO-B. In each well, $25 \mu \mathrm{L}$ of the MAO enzyme $(20 \mu \mathrm{g} / \mathrm{mL})$ were mixed with $12.5 \mu \mathrm{L}$ of the model substrate (40 and $4 \mu \mathrm{M}$ for MAO-A and -B, respectively) and $12.5 \mu \mathrm{L}$ of each candidate inhibitor. The final reaction volume was $50 \mu \mathrm{L}$. The plate was then incubated at room temperature for $1 \mathrm{~h}$. The luminescent signal was then generated by adding $50 \mu \mathrm{L}$ of the luciferin detection reagent, incubating the plate for $20 \mathrm{~min}$ at room temperature, and measuring the signal using an Infinite 200 Pro microplate reader (Tecan Italia, Cernusco sul Naviglio, Italy). For the blank, the reaction buffer was used, instead of the MAO enzyme. Each experiment also 
included a positive control with a known selective inhibitor (clorgyline for MAO-A and deprenyl for MAO-B) and negative control with buffer in place of the candidate inhibitor. Based on preliminary assays, fresh juices were tested at selected concentration ranges for each fruit or vegetable $(10-700 \mathrm{mg} / \mathrm{mL}$, overall), while concentrations of single compounds ranged from $0.03 \mathrm{mM}$ to $145 \mathrm{mM}$ for selected metabolites (quinic acid, caffeic acid, catechin, and esculin), from $4 \mathrm{nM}$ to $250 \mathrm{nM}$ for clorgyline and $12.5 \mathrm{nM}$ to $2.5 \mu \mathrm{M}$ for deprenyl.

\subsection{NMR Spectroscopy}

Kiwifruit juice samples for nuclear magnetic resonance (NMR) spectroscopy were prepared by thawing $2-3 \mathrm{~g}$ of homogenized powder, vortexing the juice, and sonicating for $15 \mathrm{~min}$ in a cold-water bath. The suspension was then centrifuged at $15,000 \times g$ for $10 \mathrm{~min}$ at $4{ }^{\circ} \mathrm{C}$, and the supernatant was transferred to a fresh tube and centrifuged at $18,000 \times g$ for $20 \mathrm{~min}$ at $4{ }^{\circ} \mathrm{C}$ to remove the remaining insoluble debris. Then, $0.56 \mathrm{~mL}$ of the soluble aqueous extracts was diluted to a final volume of $0.7 \mathrm{~mL}$ in $0.15 \mathrm{M}$ potassium phosphate buffer $(\mathrm{pH} 6.0), 0.02 \%(w / v)$ sodium azide, $5 \%(v / v) \mathrm{D}_{2} \mathrm{O}$ (Cambridge Isotope Laboratories, Cambridge, UK), and $1 \mathrm{mM}$ 4,4-dimethyl-4-silapentane-1-sulfonic acid- $\mathrm{d}_{6}$ (DSS-d $\mathrm{d}_{6}$ ) (MilliporeSigma, Milan, Italy). NMR spectra were recorded at $298 \mathrm{~K}$ using a Bruker Avance III instrument (Bruker, Karlsruhe, Germany), equipped with a triple resonance TCI cryogenic probe and operating at a ${ }^{1} \mathrm{H}$ Larmor frequency of $600.13 \mathrm{MHz}$. The $1 \mathrm{H}-\mathrm{NOESY}$ spectra were acquired with a mixing time of $100 \mathrm{~ms}$, a recycle delay of $10 \mathrm{~s}, 64$ free induction decays (FIDs), 64,000 data points, and a spectral width of $20 \mathrm{ppm}$. Spectra were processed with Topspin v3.2 (Bruker) by multiplying FIDs with an exponential weighting function, with line broadening of $0.3 \mathrm{~Hz}$, before Fourier transformation, phasing, and baseline correction. Spectra were then referenced to the DSS- $\mathrm{d}_{6}$ singlet signal and analyzed using Chenomx NMR Suite v8.0 (Chenomx, Alberta, Canada) and, by comparison, with the Biological Magnetic Resonance Bank (Retrieved 19 November 2020 from http:/ / www.bmrb.wisc.edu/). The quantity of sugars that are the most abundant metabolites was also determined by NMR analysis of six kiwifruit juice samples. Sucrose and glucose were quantified by integrating the NMR signals using DSS- $\mathrm{d}_{6}$ as an internal standard. The Chenomx software was used to quantify fructose. The resulting values were then corrected with the dilution factor and converted to milligrams per 100 grams of homogenized fruit powder, based on the starting weights and volumes (see Section 3.1 and Supplementary File S1).

\subsection{Protein Concentration Determination}

The protein concentration in fresh and neutralized kiwifruit juice was determined using Bradford reagent in a 96-well plate format [27] (see Supplementary File S2). A standard curve was prepared using BSA standards in the concentration range $0.1-1.4 \mathrm{mg} / \mathrm{mL}$. Absorbance was measured on an Infinite 200 Pro microplate reader (Tecan Italia, Cernusco sul Naviglio, Italy).

\subsection{UPLC-MS Analysis}

Fresh and neutralized kiwifruit juices were analyzed through ultra-performance liquid chromatography mass spectrometry (UPLC-MS). The analysis was carried out using an Acquity I Class UPLC system (Waters, Milford, MA, USA), connected to a Xevo G2-XS qTOF mass spectrometer (Waters). All extracts were injected into a Waters ACQUITY UPLC BEH C18 column $(2.1 \times 100 \mathrm{~mm}, 1.7 \mu \mathrm{m})$, kept at $30^{\circ} \mathrm{C}$, and the mobile phases consisted of $0.1 \%$ formic acid in water (A) and acetonitrile (B); the initial conditions were $99 \% \mathrm{~A}$ and $1 \% \mathrm{~B}$, and the following elution profile was applied: $0-1 \mathrm{~min}, 1 \% \mathrm{~B} ; 1-10 \mathrm{~min}$, $1-40 \%$ B; $10-13.50 \mathrm{~min}, 40-70 \% \mathrm{~B} ; 13.50-15.00 \mathrm{~min}, 70-90 \% \mathrm{~B} ; 15.00-16.50 \mathrm{~min}, 90-100 \%$ B; $16.50-20 \mathrm{~min}, 100 \% \mathrm{~B} ; 20-20.1 \mathrm{~min}, 100-1 \%$ B (initial conditions). Subsequently, the system was equilibrated in $99 \% \mathrm{~A}$, and the elution was complete after $25 \mathrm{~min}$. Flow rate was set to $0.35 \mathrm{~mL} / \mathrm{min}$. The mass spectrometer was equipped with an electrospray ionization (ESI) source, operating in negative mode. The settings of the ion source were already described in a previous work [28]. In addition, the samples were analyzed with two different MS 
methods to cover a wider range of $\mathrm{m} / \mathrm{z}$ : for the first method, the quadrupole MS profile was set automatically; for the second method, the profile was set on 300,400 , and $500 \mathrm{~m} / \mathrm{z}$, with fixed well and ramp time ( $25 \%$ scan time).

The UPLC-MS chromatograms were analyzed using Masslynx v4.1 software (Waters), and MS raw data were processed using Progenesis QI (Nonlinear Dynamics, Newcastle, UK). Metabolite annotations were performed, comparing $\mathrm{m} / \mathrm{z}$ values, isotope distribution, fragmentation (MS/MS), and, where feasible, retention time, with authentic standards, an in-house library of masses built using ProgenesisSDFStudio (Waters), as well as inhouse Chemsketch library (ACD Labs, Toronto, ON, Canada) and public libraries, such as mass bank (Retrieved 26 June 2021 from https:/ / massbank.eu/MassBank/Search), Metlin (Retrieved 26 June 2021 from https: / / metlin.scripps.edu), ChemSpider (Retrieved 26 June 2021 from http:/ / www.chemspider.com).

\subsection{Quinic Acid Quantification}

The calibration curve of D-(-)-quinic acid was prepared by diluting the standard solution at seven different concentrations, for analysis by UPLC-MS, as described above. Linearity was 0.9993 , over the quinic concentration range of $0.5-4 \mu \mathrm{g} / \mathrm{mL}$, derived using the least squares regression analysis. Three replicate samples were used for quantification. In order to overcome possible matrix effects, due to ESI source, various dilutions of the sample were prepared, and spiking experiments, as described by Toffali et al. [29], were used to determine the presence/absence of matrix effects for each dilution. The quantification was performed at the dilution of $1 / 1600$, where the matrix effect was completely absent.

\subsection{Data Analysis}

Statistical analysis was carried out using Prism v9.0 (GraphPad Software, San Diego, CA, USA). Significant differences between samples were determined by one-way analysis of variance (ANOVA), followed by Dunnett's or Tukey's post hoc tests. $\mathrm{IC}_{50}$ values were calculated by nonlinear regression.

\section{Results}

\subsection{Kiwifruit as a Model Fruit for MAO Inhibition Assay Optimization and Activity}

Microplate assays to test the ability of compounds to inhibit MAO-A and -B were optimized for use with fruit and vegetable extracts by testing freshly extracted kiwifruit juice. Freshly extracted fruit and vegetable juice is acidic ( $\mathrm{pH} \sim 3)$, due to the abundance of organic acids (mainly citric and malic acids), ascorbic acid, and sugars. To evaluate whether $\mathrm{pH}$ was an interfering factor in the assay, the $\mathrm{pH}$ of the fresh juice was adjusted to 4,5 , and 7.5 and tested its ability to inhibit MAO-A and -B. Low $\mathrm{pH}$ strongly inhibited MAO activity $\left[\mathrm{F}_{(4,10)}=2424 ; p<0.0001\right]$, so all the subsequent experiments were adjusted to $\mathrm{pH} 7.5$, the same $\mathrm{pH}$ of the assay buffer, to ensure that inhibitory effects were directly caused by the metabolites, rather than the low $\mathrm{pH}$ (Figure 1).

To exclude the possibility that bulk primary metabolites (such as sugars and citric and malic acid) and ascorbic acid were responsible for the inhibitory activity, vehicle solutions were created using these major components, detected in kiwifruit by NMR spectroscopy (Supplementary File S1) and reported in scientific literature. The composition of the complete vehicle solution was $10 \mathrm{~g} / \mathrm{L}$ sucrose, $33 \mathrm{~g} / \mathrm{L}$ fructose, $36 \mathrm{~g} / \mathrm{L}$ glucose, $0.7 \mathrm{~g} / \mathrm{L}$ ascorbic acid, $9 \mathrm{~g} / \mathrm{L}$ citric acid, and $9 \mathrm{~g} / \mathrm{L}$ malic acid. Four additional vehicle solutions were produced, containing, respectively, only the sugars, citric acid, and/or malic acid. The inhibitory activity of the complete and partial vehicle solutions against the fresh (FK) and neutralized juice (FK), all adjusted to $\mathrm{pH} 7.5$, were then tested. Only the fresh juice showed significant activity, with greater activity against MAO-A than MAO-B (Figure 2). 
a)

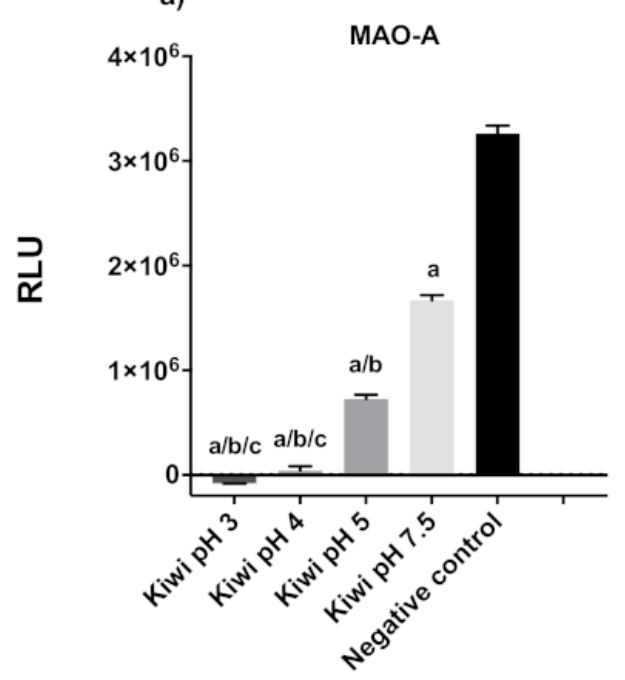

b)

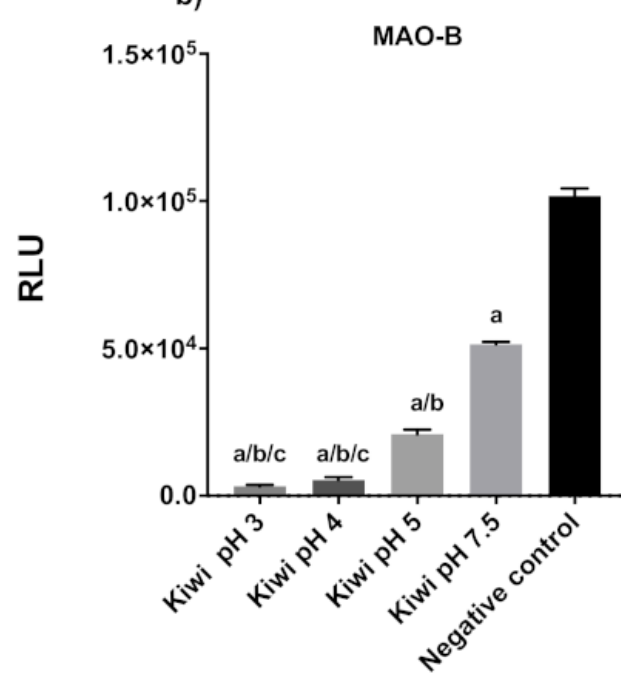

Figure 1. Effects of $\mathrm{pH}$ on MAOs activity. MAO-Glo assay of kiwifruit juice (at different $\mathrm{pH}$ values) to test for the inhibition of human MAO-A (a) and -B (b). A total of $12.5 \mu \mathrm{L}$ of kiwifruit juice, corresponding to $16.8 \mathrm{mg}$ of fresh fruit, was used. Activity was measured in relative light units (RLUs). Values were evaluated by one-way ANOVA, followed by Tukey's test, and expressed as means $\pm \mathrm{SD}$ ( $n=4$ per group); ${ }^{\mathrm{a}} p \leq 0.0001$ vs. negative control group, ${ }^{\mathrm{b}} p \leq 0.0001 \mathrm{vs}$. $\mathrm{pH} 7.5$, ${ }^{\mathrm{c}} p \leq 0.0001$ vs. pH 5 .

a)

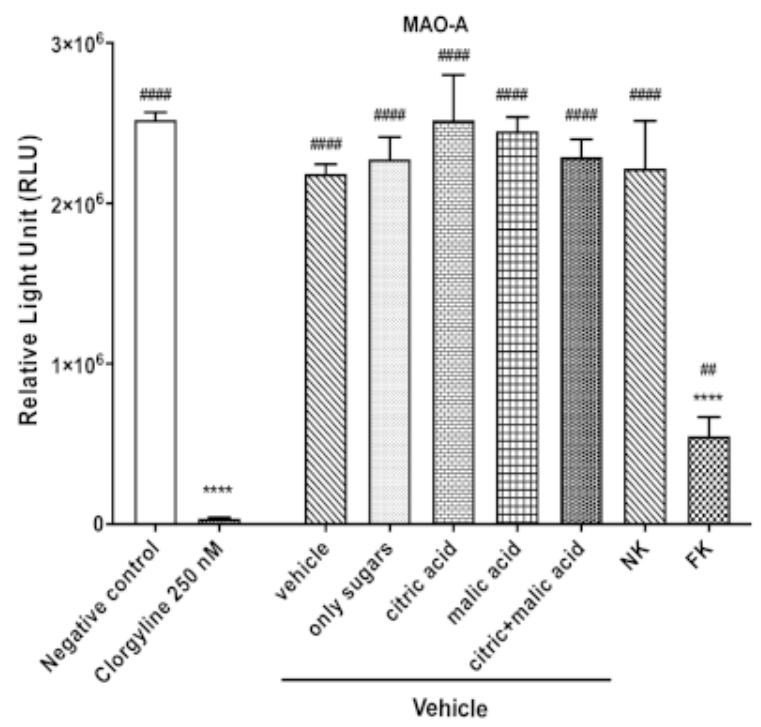

b)

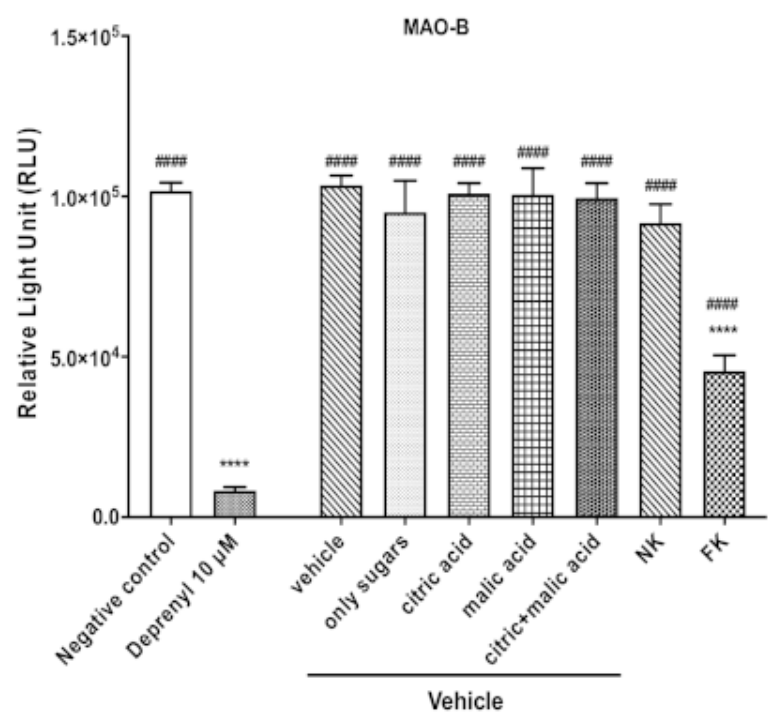

Figure 2. Effects of fresh and neutralized kiwifruit juice and matching vehicle solutions on MAO activity. A total of $12.5 \mu \mathrm{L}$ of kiwifruit juice, corresponding to $16.8 \mathrm{mg}$ of fresh fruit, was used and equivalent amounts of the other samples. The samples were tested for their ability to inhibit (a) MAO-A and (b) -B activity using the bioluminescent MAO-Glo assay, with values expressed as relative light units (RLUs), compared to $250 \mathrm{nM}$ clorgyline and $2.5 \mu \mathrm{M}$ deprenyl as positive controls for MAO-A and -B, respectively, and a negative control with buffer in place of the inhibitor. Data were evaluated by one-way ANOVA, followed by Tukey's test, and expressed as means $\pm \operatorname{SD}(n=4$

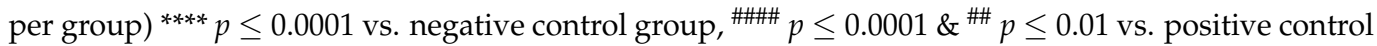
group (clorgyline/deprenyl). $\mathrm{NK}=$ neutralized kiwifruit, $\mathrm{FK}=$ fresh kiwifruit.

Then, the role of fruit proteins in the observed inhibitory effect was evaluated, since kiwifruits contain proteolytic enzymes, such as actinidin [30]. The protein concentration in kiwifruit (active) and neutralized juice (inactive) was found to be the same, suggesting that 
proteins are not responsible for the inhibition of MAO. The protein concentration in the fresh juice was $0.548 \pm 0.099 \mathrm{mg} / \mathrm{mL}$ and that in the neutralized juice was $0.573 \pm 0.215 \mathrm{mg} / \mathrm{mL}$ (Table S1 and Figure S1). To confirm that kiwifruit proteins do not inhibit MAO, a proteinfree derivative of the fresh juice was prepared by passing it through filters, with molecular weight cut-off (MWCO) values of 3 and $10 \mathrm{kDa}$, before repeating the inhibition assays. As expected, there were no significant differences between the fresh juice and two proteindepleted filtrates, in terms of their ability to inhibit MAO-A and -B (Figure 3).



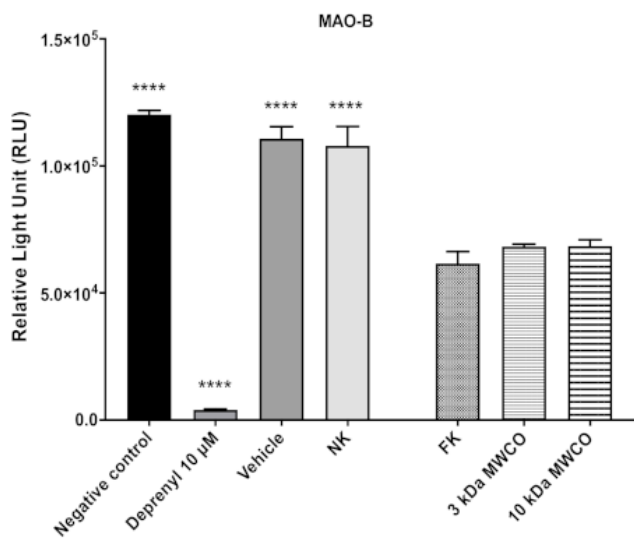

Figure 3. Effect of fresh and protein-depleted kiwifruit juice on MAO activity. A total of $12.5 \mu \mathrm{L}$ of fresh or protein-depleted kiwifruit juice, corresponding to $16.8 \mathrm{mg}$ of fresh fruit, was used. The samples were tested for their ability to inhibit (a) MAO-A and (b) -B activity using the bioluminescent MAO-Glo assay, with values expressed as relative light units (RLUs), compared to $250 \mathrm{nM}$ clorgyline and $2.5 \mu \mathrm{M}$ deprenyl as positive controls for MAO-A and -B, respectively, and a negative control with buffer in place of the inhibitor. Data were evaluated by one-way ANOVA, followed by Dunnett's test, and expressed as means $\pm \mathrm{SD}\left(n=4\right.$ per group; ${ }^{* * * *} p \leq 0.0001$ vs. fresh kiwifruit juice group); $\mathrm{MWCO}=$ molecular weight cut-off; $\mathrm{NK}=$ neutralized kiwifruit; FK = fresh kiwifruit.

Having excluded proteins, sugars, organic acids, and ascorbic acid as the source of the inhibitory activity, a list of metabolites present in the active fresh juice, but not the inactive neutralized juice, was prepared, based on the heat map from the untargeted metabolomic analysis (Supplementary File S3). The list of putatively identified, specialized metabolites that were more abundant in the fresh juice included caffeic acid hexoses and di-hexoses, other caffeic acid derivatives, esculin, catechin, quinic acid, and quinic acid derivatives.

The effect of different concentrations of kiwifruit juice was compared to clorgyline and deprenyl standards in the MAO inhibition assay, revealing that the juice has greater activity against MAO-A and lower against MAO-B (Table 1). A list of metabolites that were promising candidate inhibitors was prepared, according to their abundance in fresh kiwifruit juice or a high ratio between fresh and neutralized kiwifruit juice (see Supplementary File S3). Based on these criteria, caffeic acid, quinic acid, catechin, and esculin were selected for further experiments. Since UPLC-MS data showed that quinic acid was the most abundant candidate, and its concentration $(491.26 \pm 1.80 \mathrm{mg} / 100 \mathrm{~g}$ fruit fresh weight) was also determined by mass spectrometry (see Section 2.8). The effects of caffeic acid, quinic acid, catechin, and esculin standards were compared to clorgyline and deprenyl standards in the MAO inhibition assay (Table 1). It was found that catechin and esculin inhibited both enzymes similarly, caffeic acid inhibited both enzymes but was more active against MAO-B, whereas quinic acid showed selective activity against MAO-B. 
Table 1. $\mathrm{IC}_{50}$ values of kiwifruit and its secondary metabolites.

\begin{tabular}{|c|c|c|c|c|}
\hline \multirow[t]{3}{*}{ Compound } & \multicolumn{4}{|c|}{$\mathrm{IC}_{50}$ Value } \\
\hline & \multicolumn{2}{|c|}{ MAO-A $^{a}$} & \multicolumn{2}{|c|}{ MAO-B ${ }^{a}$} \\
\hline & $(\mathrm{mg} / \mathrm{mL})^{\mathrm{b}}$ & $M^{c}$ & $(\mathrm{mg} / \mathrm{mL})^{\mathrm{b}}$ & $M^{c}$ \\
\hline Clorgyline (MAO-A control) & $5.49 \times 10^{-6} \pm 2.4 \times 10^{-7}$ & $0.0178 \pm 0.0007 \mu \mathrm{M}$ & - & - \\
\hline Deprenyl (MAO-B control) & - & - & $1.96 \times 10^{-5} \pm 8.2 \times 10^{-7}$ & $0.1048 \pm 0.004 \mu \mathrm{M}$ \\
\hline Kiwifruit ${ }^{b}$ & $86 \pm 2.6$ & - & $122.9 \pm 5.5$ & - \\
\hline D-(-)-Quinic acid & - & - & $6.60 \pm 0.25$ & $34.37 \pm 1.307 \mathrm{mM}$ \\
\hline Caffeic acid & $0.49 \pm 0.02$ & $2.747 \pm 0.126 \mathrm{mM}$ & $0.08 \pm 0.005$ & $0.439 \pm 0.03 \mathrm{mM}$ \\
\hline Catechin & $1.88 \pm 0.04$ & $6.464 \pm 0.121 \mathrm{mM}$ & $1.17 \pm 0.04$ & $4.029 \pm 0.122 \mathrm{mM}$ \\
\hline Esculin & $3.93 \pm 0.15$ & $11.55 \pm 0.4305 \mathrm{mM}$ & $4.10 \pm 0.13$ & $12.06 \pm 0.3721 \mathrm{mM}$ \\
\hline
\end{tabular}

The ability of kiwifruit juice, quinic acid, caffeic acid, catechin, and esculin to inhibit MAO-A and -B was determined using the MAO-Glo assay, compared to clorgyline and $\mathrm{R}-(-)$-deprenyl as positive controls for MAO-A and $-\mathrm{B}$, respectively. ${ }^{a}$ Each inhibitory activity is expressed as the mean of $50 \%$ inhibitory concentration $\left(\mathrm{IC}_{50}\right)$ of quadruplicate determinations, obtained by interpolation of the concentration-inhibition curves. ${ }^{\mathrm{b}} \mathrm{mg}$ fruit fresh weight $/ \mathrm{mL} .{ }^{c}$ For standards metabolite, data are also shown in molarity $(\mathrm{M})$ for comparative purposes.

\subsection{Common Fruits and Vegetables Inhibit Human $M A O-A$ and $-B$}

Having optimized the MAO inhibition assays, using kiwifruit as the model, 17 additional samples, representing common fruits and vegetables were tested, using clorgyline and deprenyl as controls. Each sample was tested at different concentrations to establish the $\mathrm{IC}_{50}$, as shown in Table 2. MAO-A was most strongly inhibited by extracts of red chicory, followed by cucumber and fennel. In contrast, MAO-B was most strongly inhibited by extracts of cucumber, followed by red chicory and ripe bell pepper.

Table 2. $\mathrm{IC}_{50}$ values of common fruit and vegetable extracts against MAO-A and -B.

\begin{tabular}{|c|c|c|}
\hline \multirow[t]{2}{*}{ Sample or Compound Tested } & \multicolumn{2}{|c|}{$\mathrm{IC}_{50}$ Values $(\mathrm{mg} / \mathrm{mL})^{\mathrm{a}}$} \\
\hline & MAO-A ${ }^{b}$ & MAO-B ${ }^{b}$ \\
\hline Clorgyline & $5.49 \times 10^{-6} \pm 2.4 \times 10^{-7}$ & - \\
\hline R-(-)-Deprenyl & - & $1.96 \times 10^{-5} \pm 8.2 \times 10^{-7}$ \\
\hline Kiwifruit (Actinidia deliciosa) & $86.0 \pm 2.6$ & $122.9 \pm 5.5$ \\
\hline Apple (Malus domestica) cv. golden delicious & $186.5 \pm 5.9$ & ND \\
\hline Apple (Malus domestica) cv. prussian & $159.0 \pm 5.2$ & $100.7 \pm 5.3$ \\
\hline Carrot (Daucus carota) & $79.7 \pm 4.0$ & $61.5 \pm 1.7$ \\
\hline Cherry (Prunus avium) cv. black star & $79.0 \pm 1.9$ & $84.9 \pm 2.7$ \\
\hline Cherry (Prunus avium) cv. roana & $52.5 \pm 0.8$ & $56.3 \pm 2.0$ \\
\hline Cucumber (Cucumis sativus) & $15.7 \pm 0.5$ & $20.8 \pm 0.7$ \\
\hline Fennel (Foeniculum vulgare) & $47.1 \pm 2.4$ & $66.7 \pm 1.1$ \\
\hline Lettuce (Lactuca sativa) & $69.0 \pm 2.4$ & $69.8 \pm 1.9$ \\
\hline Nectarine (Prunus persica) & $133.9 \pm 4.7$ & $155.5 \pm 7.0$ \\
\hline Onion (Allium cepa) & $93.0 \pm 3.7$ & $113.7 \pm 3.4$ \\
\hline Peach (Prunus persica) & $103.7 \pm 2.7$ & $98.3 \pm 5.0$ \\
\hline Pear (Pyrus communis) & $106.3 \pm 3.0$ & $97.0 \pm 3.0$ \\
\hline Red chicory (Cichorium intybus) & $13.8 \pm 0.3$ & $29.3 \pm 0.6$ \\
\hline Ripe bell pepper (Capsicum annuum) & $59.0 \pm 2.7$ & $38.7 \pm 1.9$ \\
\hline Shallot (Allium ascalonicum) & $48.2 \pm 1.9$ & $47.8 \pm 1.7$ \\
\hline Tomato (Solanum lycopersicum) & $81.0 \pm 2.8$ & $103.5 \pm 3.0$ \\
\hline Unripe bell pepper (Capsicum annuum) & $74.8 \pm 4.4$ & $43.6 \pm 3.3$ \\
\hline
\end{tabular}

The ability of common fruit and vegetable extracts to inhibit MAO-A and -B was determined using the MAO-Glo assay, compared to clorgyline and deprenyl as positive controls for MAO-A and -B, respectively. ND = not determined. ${ }^{\text {a }}$ Inhibitory activity of fruits/vegetables is expressed as $\mathrm{mg}$ fresh weight $/ \mathrm{mL} .{ }^{\mathrm{b}}$ Each inhibitory activity is expressed as the mean of $50 \%$ inhibitory concentration ( $\mathrm{IC}_{50} \mathrm{in} \mathrm{mg} / \mathrm{mL}$ ) of quadruplicate determinations, obtained by interpolation of the concentration-inhibition curves.

The chromatographic profiles of the above samples were explored by UPLC-ESI-MS, as shown in Table 3 and Supplementary File S1. The main peaks were tentatively annotated. 
Table 3. Metabolites annotated and their occurrence in the fruits and vegetables under investigation.

\begin{tabular}{|c|c|c|c|c|c|c|c|c|}
\hline Species & Id & Rt (min) & $m / z(-)$ Detected & $m / z$ (-) Expected & $\begin{array}{l}\text { Elemental } \\
\text { Formula }\end{array}$ & $\begin{array}{c}\text { Putative } \\
\text { Identification }\end{array}$ & Fragments & Main Adduct \\
\hline $\begin{array}{l}\text { DC, FV, AD, LS, CI, MDG, MDP, } \\
\text { PC, PPN, PP, RCA, UCA, SL }\end{array}$ & 1 & 0.80 & 533.174 & 533.171 & $\mathrm{C}_{18} \mathrm{H}_{32} \mathrm{O}_{15}$ & $\begin{array}{l}\text { glucose-glucose- } \\
\text { rhamnose }\end{array}$ & & $\mathrm{fa}$ \\
\hline $\begin{array}{c}\text { DC, AC, AA, FV, AD, LS, CI, } \\
\text { MDG, MDP, PC, PPN, PP, RCA, } \\
\text { UCA, SL }\end{array}$ & 2 & 0.80 & 387.115 & 387.113 & $\mathrm{C}_{12} \mathrm{H}_{22} \mathrm{O}_{11}$ & sucrose & & fa \\
\hline DC, CS, FV, CI, MDP, PP, UCA & 3 & 0.75 & 96.961 & 96.969 & $\mathrm{H}_{3} \mathrm{PO}_{4}$ & phosphate & & $\mathrm{M}-1 \mathrm{H}^{+}$ \\
\hline $\begin{array}{l}\text { DC, CS, PAR, FV, AD, LS, CI, } \\
\text { MDG, MDP, PC, PPN, PP, SL }\end{array}$ & 4 & 0.86 & 133.014 & 133.013 & $\mathrm{C}_{4} \mathrm{H}_{6} \mathrm{O}_{5}$ & malic acid & 115.003 & $\mathrm{M}-1 \mathrm{H}^{+}$ \\
\hline $\begin{array}{c}\text { DC, CS, AC, AA, FV, AD, LS, } \\
\text { CI, MDG, MDP, PPN, PP, RCA, } \\
\text { UCA, SL }\end{array}$ & 5 & 1.32 & 191.020 & 191.019 & $\mathrm{C}_{6} \mathrm{H}_{8} \mathrm{O}_{7}$ & citric acid & 111.008 & $\mathrm{M}-1 \mathrm{H}^{+}$ \\
\hline DC & 6 & 4.97 & 431.120 & 431.118 & $\mathrm{C}_{17} \mathrm{H}_{22} \mathrm{O}_{10}$ & sinapic acid hexoside & 222.993 & fa \\
\hline CS & 7 & 3.45 & 315.072 & 315.071 & $\mathrm{C}_{13} \mathrm{H}_{16} \mathrm{O}_{9}$ & $\begin{array}{c}\text { dihydroxybenzoic acid } \\
\text { hexoside }\end{array}$ & 150.016 & $\mathrm{M}-1 \mathrm{H}^{+}$ \\
\hline PAB, PAR, PPN, PP & 8 & 4.00 & 353.088 & 353.087 & $\mathrm{C}_{16} \mathrm{H}_{18} \mathrm{O}_{9}$ & caffeoyl quinic acid & $135.034 ; 179.034$ & $\mathrm{M}-1 \mathrm{H}^{+}$ \\
\hline PAB, PAR & 9 & 4.58 & 337.093 & 337.092 & $\mathrm{C}_{16} \mathrm{H}_{18} \mathrm{O}_{8}$ & coumaroyl quinic acid & 163 & $\mathrm{M}-1 \mathrm{H}^{+}$ \\
\hline PAB, PAR & 10 & 4.66 & 477.161 & 477.16 & $\mathrm{C}_{19} \mathrm{H}_{28} \mathrm{O}_{11}$ & $\begin{array}{c}\text { caffeoyl quinic acid } \\
\text { derivative }\end{array}$ & $\begin{array}{c}135.034 ; 179.034 \\
353.087\end{array}$ & $\mathrm{fa}$ \\
\hline PAR & 12 & 4.72 & 593.151 & 593.15 & $\mathrm{C}_{27} \mathrm{H}_{31} \mathrm{O}_{15}$ & cyanidin-O-rutinoside & 284.032 & $\mathrm{M}-1 \mathrm{H}^{+}$ \\
\hline $\begin{array}{l}\text { PAR, AD, LS, CI, MDG, MDP, } \\
\text { PC, PPN, PP, RCA, UCA, SL }\end{array}$ & 13 & 0.79 & 191.056 & 191.055 & $\mathrm{C}_{7} \mathrm{H}_{12} \mathrm{O}_{6}$ & quinic acid & 127.045 & $\mathrm{M}-1 \mathrm{H}^{+}$ \\
\hline $\mathrm{AC}, \mathrm{AA}$ & 14 & 1.87 & 873.273 & 873.272 & $\mathrm{C}_{30} \mathrm{H}_{52} \mathrm{O}_{26}$ & penta-hexose & 827.268 & fa \\
\hline $\mathrm{AC}, \mathrm{AA}$ & 15 & 2.22 & 873.273 & 873.272 & $\mathrm{C}_{30} \mathrm{H}_{52} \mathrm{O}_{26}$ & penta-hexose & 827.268 & $\mathrm{fa}$ \\
\hline $\mathrm{AC}, \mathrm{AA}, \mathrm{LS}$ & 16 & 2.47 & 1035.327 & 1035.325 & $\mathrm{C}_{36} \mathrm{H}_{62} \mathrm{O}_{31}$ & hexa-hexose & 989.322 & fa \\
\hline $\mathrm{AC}, \mathrm{AA}$ & 17 & 2.54 & 1197.379 & 1197.377 & $\mathrm{C}_{42} \mathrm{H}_{72} \mathrm{O}_{36}$ & hepta-hexose & 1151.374 & fa \\
\hline $\mathrm{AC}, \mathrm{AA}$ & 18 & 5.64 & 625.141 & 625.14 & $\mathrm{C}_{27} \mathrm{H}_{30} \mathrm{O}_{17}$ & quercetin-O-dihexoside & $301.034 ; 464.087$ & $\mathrm{M}-1 \mathrm{H}^{+}$ \\
\hline $\mathrm{AC}, \mathrm{AA}$ & 19 & 5.83 & 639.156 & 639.156 & $\mathrm{C}_{28} \mathrm{H}_{32} \mathrm{O}_{17}$ & $\begin{array}{l}\text { rhamnetin/isorhamnetin- } \\
\text { O-dihexoside }\end{array}$ & $313.034 ; 315.049$ & $\mathrm{M}-1 \mathrm{H}^{+}$ \\
\hline $\mathrm{AC}, \mathrm{AA}$ & 20 & 7.23 & 463.088 & 463.087 & $\mathrm{C}_{21} \mathrm{H}_{20} \mathrm{O}_{12}$ & quercetin-O-hexoside & $\begin{array}{c}\text { 151.002; } 178.997 \\
301.034\end{array}$ & $\mathrm{M}-1 \mathrm{H}^{+}$ \\
\hline $\mathrm{AC}, \mathrm{AA}$ & 21 & 7.56 & 477.103 & 477.103 & $\mathrm{C}_{22} \mathrm{H}_{22} \mathrm{O}_{12}$ & $\begin{array}{c}\text { rhamnetin/isorhamnetin- } \\
\text { O-hexoside }\end{array}$ & 314.042 & $\mathrm{M}-1 \mathrm{H}^{+}$ \\
\hline $\mathrm{AC}, \mathrm{AA}, \mathrm{LS}, \mathrm{CI}$ & 22 & 0.82 & 549.166 & 549.166 & $\mathrm{C}_{18} \mathrm{H}_{32} \mathrm{O}_{16}$ & tri-hexose & & fa \\
\hline
\end{tabular}


Table 3. Cont.

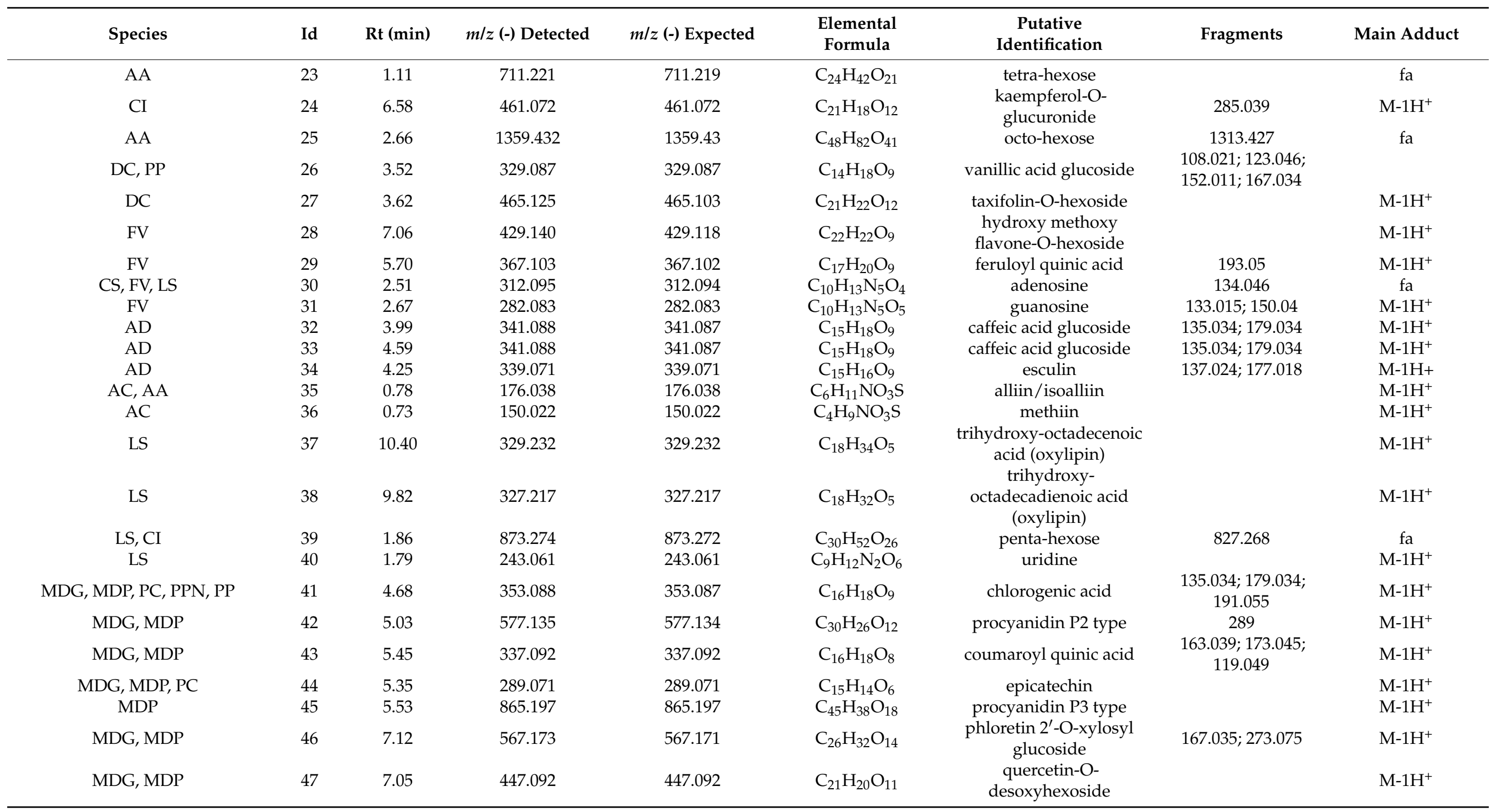


Table 3. Cont.




Table 3. Cont.

\begin{tabular}{|c|c|c|c|c|c|c|c|c|}
\hline Species & Id & Rt (min) & $m / z(-)$ Detected & $m / z(-)$ Expected & $\begin{array}{l}\text { Elemental } \\
\text { Formula }\end{array}$ & $\begin{array}{c}\text { Putative } \\
\text { Identification }\end{array}$ & Fragments & Main Adduct \\
\hline $\begin{array}{c}\mathrm{DC}, \mathrm{CS}, \mathrm{AC}, \mathrm{AA}, \mathrm{FV}, \mathrm{AD}, \mathrm{LS}, \\
\text { CI, RCA, UCA }\end{array}$ & 69 & 0.72 & 145.061 & 145.061 & $\mathrm{C}_{5} \mathrm{H}_{10} \mathrm{~N}_{2} \mathrm{O}_{3}$ & glutamine & & $\mathrm{M}-1 \mathrm{H}^{+}$ \\
\hline DC, CS, AA, CI, UCA, SL & 70 & 0.72 & 132.030 & 132.029 & $\mathrm{C}_{4} \mathrm{H}_{7} \mathrm{NO}_{4}$ & $\begin{array}{c}\text { aspartic acid } \\
\text { kaempferol-O- }\end{array}$ & & $\mathrm{M}-1 \mathrm{H}^{+}$ \\
\hline CS & 71 & 5.43 & 901.241 & 901.24 & $\mathrm{C}_{42} \mathrm{H}_{46} \mathrm{O}_{22}$ & $\begin{array}{l}\text { (coumaroyl) glucoside } \\
\text { rutinoside }\end{array}$ & 739.186 & $\mathrm{M}-1 \mathrm{H}^{+}$ \\
\hline $\begin{array}{c}\text { PAB, PAR, MDG, MDP, PC, } \\
\text { PPN, PP }\end{array}$ & 72 & 0.78 & 181.071 & 181.071 & $\mathrm{C}_{6} \mathrm{H}_{14} \mathrm{O}_{6}$ & sorbitol & & $\mathrm{M}-1 \mathrm{H}^{+}$ \\
\hline $\begin{array}{c}\mathrm{DC}, \mathrm{PAB}, \mathrm{PAR}, \mathrm{FV}, \mathrm{AD}, \mathrm{PPN}, \\
\text { SL }\end{array}$ & 73 & 0.74 & 195.050 & 195.05 & $\mathrm{C}_{6} \mathrm{H}_{12} \mathrm{O}_{7}$ & gluconic acid & & $\mathrm{M}-1 \mathrm{H}^{+}$ \\
\hline RCA, UCA & 74 & 0.80 & 175.024 & 175.024 & $\mathrm{C}_{6} \mathrm{H}_{8} \mathrm{O}_{6}$ & ascorbic acid & & $\mathrm{M}-1 \mathrm{H}^{+}$ \\
\hline RCA, UCA, SL & 75 & 1.05 & 175.024 & 175.024 & $\mathrm{C}_{6} \mathrm{H}_{8} \mathrm{O}_{6}$ & ascorbic acid & & $\mathrm{M}-1 \mathrm{H}^{+}$ \\
\hline AD, MDG, SL & 76 & 0.73 & 146.042 & 146.45 & $\mathrm{C}_{5} \mathrm{H}_{8} \mathrm{NO}_{4}$ & glutamic acid & & $\mathrm{M}-1 \mathrm{H}^{+}$ \\
\hline $\begin{array}{c}\text { DC, PAB, PAR, CI, MDG, PC, } \\
\text { PPN, RCA, UCA }\end{array}$ & 77 & 0.73 & 131.045 & 131.045 & $\mathrm{C}_{4} \mathrm{H}_{8} \mathrm{~N}_{2} \mathrm{O}_{3}$ & asparagine & & $\mathrm{M}-1 \mathrm{H}^{+}$ \\
\hline PAB, PAR & 78 & 0.77 & 343.124 & 343.124 & $\mathrm{C}_{12} \mathrm{H}_{24} \mathrm{O}_{11}$ & sorbitol-glucose & 181.069 & $\mathrm{M}-1 \mathrm{H}^{+}$ \\
\hline
\end{tabular}




\section{Discussion}

In search of possible molecular targets of fresh fruit and vegetables activity on brain health, extracts from 14 species were screened for their ability to inhibit the human enzymes $\mathrm{MAO}-\mathrm{A}$ and -B in vitro.

The knowledge of the ability of edible fruits and vegetables to inhibit MAO-A and B enzymes has a double meaning. On one hand, the inhibition of the MAOs through diet could contribute to the control of pathologies dependent on the activity of these enzymes. On the other hand, knowledge of the biological activities of diet components is necessary to design the dietary restrictions when MAOs inhibitor drugs are taken (e.g., the cheese reaction in patients under MAOIs treatment could lead to a hypertensive crisis after eating tyramine-rich foods) [31]. Indeed, biogenic amines are abundantly contained in processed foods; however, even fresh fruits and vegetables can contain them, albeit in much smaller quantities [32].

Fruit and vegetable tissues are complex mixtures of insoluble macromolecules (e.g., polysaccharides, structural proteins, lignin, etc.), lipophilic molecules, soluble proteins and carbohydrates, and a complex array of small-molecule metabolites, many with bioactive properties [33]. The insoluble components comprise of most of the dietary fiber, which is largely removed during the juice preparation process (see Section 2.3); whereas the soluble portion still retains a complex mixture of molecules, including proteins, abundant primary metabolites (e.g., sugars, amino acids, and organic acids), and specialized secondary metabolites in various classes, some of which are at low level [34]. In principle, all these components could inhibit MAO-A and/or - B. Moreover, fruits and vegetables are acidic due to the high content of organic acids in the vacuolar sap [35], with citric and malic acids being predominant in many fleshy fruits such as kiwifruit [36]. The effect of kiwifruit $\mathrm{pH}$ on the in vitro MAOs activity assay was evaluated, revealing that both enzymes are inhibited per se by the low $\mathrm{pH}$ of fruit juice, with a decrease of inhibition as the $\mathrm{pH}$ approaches neutrality. The issue of $\mathrm{pH}$ was already addressed by Mazzio and colleagues [16], while others have neglected this aspect hence their data may include false positive results. In addition, since fruits such as kiwifruit, fig, papaya and pineapple contain proteolytic enzymes that could damage MAOs, it was also necessary to exclude the possibility that proteases present in the fruit extracts were responsible for MAO inhibition. The assays showed that the protein-free juice adjusted to $\mathrm{pH} 7.5$ retained the ability to inhibit both enzymes, confirming that proteases were not responsible for the inhibitory activity observed in vitro for kiwifruit. Moreover, the use of "neutralized juice" devoid of many small, polar metabolites and 'vehicle solutions' pointed at a group of specialized metabolites as possible responsible for the inhibitory activity. The comparison of fresh and neutralized juices allowed the selection of a list of candidate specialized metabolites most likely to inhibit $\mathrm{MAO}-\mathrm{A}$ and $-\mathrm{B}$, specifically those present in large quantities and those exclusively present in the fresh juice (see Supplementary File S3). This resolved the list of candidates to caffeic acid glucosyl derivatives, catechin, esculin and quinic acid. When tested individually, caffeic acid, catechin and esculin showed non-selective inhibitory activity against both MAOs, whereas quinic acid showed selective inhibitory activity against MAO-B. Caffeic acid, caffeic acid derivatives and catechin (all representing the phenylpropanoid family) have already been reported for their ability to inhibit MAO, but this is the first report of the inhibitory activity of esculin [21,37]. For quinic acid, one previous study described the ability of this molecule to protect rats from aluminum chloride-induced dementia and suggested non-selective inhibition of MAO as a potential mechanism [38]. The selectivity of caffeoylquinic acid derivatives is unclear: two previous articles [37,39] provide evidence for selective activity against MAO-B, whereas another [40] also showed an effect against MAO-A.

According to the results of this work the most interesting specialized metabolite is quinic acid which is mainly and abundantly found in plants as an ester with other secondary metabolites, especially hydroxycinnamic acids such as caffeic acid, and in these forms it is widespread within the plant kingdom [41]. Free quinic acid is usually found at low levels 
$(<100 \mathrm{mg} / 100 \mathrm{~g}$ fresh weight) in fruits and vegetables and edible fruits with high levels of quinic acid are rare [42], since ripe fleshy fruits generally accumulate citric and malic acids as major organic acids. Exceptions include black chokeberry (Aronia melanocarpa) [43], Ponkan mandarin (Citrus reticulata) and kiwifruit [44]. Free quinic acid is also found in some processed foods due to ester hydrolysis, for example during the roasting of coffee beans [45]. In our analysis, we found that the relative amount of free quinic acid is generally higher in fruits compared with the other plant organs, as shown in Supplementary File S1.

In addition, the in vivo bioavailability of pure quinic acid is not reported in the literature, but its recovery in human serum after coffee consumption suggests it can reach the blood [46] and high levels of quinic acid were detected in ileostomy fluids after the consumption of an apple smoothie $(\sim 70 \%)$ [47]. The level of quinic acid in the fresh kiwifruit juice was $\sim 492 \mathrm{mg} / 100 \mathrm{~g}$ of fresh fruit, in line with that reported in the literature (390 mg/100 g fresh weight [48]). The high level of quinic acid in kiwifruits and the potential bioavailability of this compound suggest that the promising in vitro activity may be replicated in vivo, and this should be now addressed in further studies. It should be noticed that all polyphenols, including catechin, have poor bioavailability and a limited ability to cross the blood-brain barrier, which hinders their clinical development [49]. However, nanotechnology could help to overcome this challenge by improving penetration and absorption [50].

If the evaluation of the possible MAO-A and - $\mathrm{B}$ inhibiting activity by the commonly consumed fresh fruits is poorly known, the activity of fresh vegetable is completely unknown. Thus, different tissues of common vegetable crops, including unripe fruits (cucumber, green bell pepper), ripe fruits (bell pepper, tomato), leaves (red chicory, lettuce), roots (carrot), shoots (fennel), and bulbs (onion, shallot) were tested. All of them showed some ability to inhibit MAO-A and -B in vitro.

The inhibition of MAO-A and/or -B has been extensively reported for extracts of many medicinal plants, including Artemisia ( $\mathrm{IC}_{50}$ MAO-B $<0.7 \mathrm{mg} / \mathrm{mL}$ ), Perilla $\left(\mathrm{IC}_{50} \mathrm{MAO}-\mathrm{B}<0.2 \mathrm{mg} / \mathrm{mL}\right)$, Glycyrrhiza species $\left(\mathrm{IC}_{50} \mathrm{MAO}-\mathrm{B}<0.07 \mathrm{mg} / \mathrm{mL}\right.$ ), Psoralea corylifolia seeds $\left(\mathrm{IC}_{50} \mathrm{MAO}-\mathrm{B}=0.054 \mathrm{mg} / \mathrm{mL}\right)$, Hypericum afrum $\left(\mathrm{IC}_{50} \mathrm{MAO}-\mathrm{A}=3.37 \mu \mathrm{g} / \mathrm{mL}\right.$ and $\mathrm{IC}_{50} \mathrm{MAO}-\mathrm{B}=13.50 \mu \mathrm{g} / \mathrm{mL}$ ), and, of course, Banisteriopsis caapi ( $\mathrm{IC}_{50}$ MAO-A $\sim 0.01-0.4 \mu \mathrm{g} / \mathrm{mL}$ ), one of the ingredients of the hallucinogenic brew Ayahuasca [16,51,52]. Although fruits and vegetables generally inhibit MAO-A and -B to a lesser degree than herbs and medicinal plants, they are consumed in much greater quantities in the diet.

Few reports have been published on this topic, and most considered extracts of dried, raw material, rather than fresh tissue or used extraction methods involving solvents. These issues hinder comparison with the results of this work because the juices in this study were obtained from nitrogen-frozen fresh material, in order to use raw material as similar as possible to fresh produce consumed in the diet.

Another issue regards the inhibiting power of the individual compounds tested, since in this work MAO-A and -B inhibition was exerted at millimolar (from 0.4 to 34.73) concentration range (see Table 1). It cannot be excluded that the inhibition of the whole extract could depend on the small additive/synergistic contributions of many metabolites, without a predominant role of specific individual compounds. These mechanisms are often overlooked, since the typical research approach is devoted at reducing complexity to identify single active compounds. This explains, in general, why single molecules can't replace the natural phytocomplexes of fruits and vegetables to achieve the health benefits [53].

This aspect also could be addressed in future studies analyzing the single active components and how their combination affects the activity.

Supplementary Materials: The following supporting information can be downloaded at: https: / / www.mdpi.com/article/10.3390/plants11030346/s1, File S1: Chromatographic profiles; File S2: Bradford Assay; File S3: Untargeted metabolomics data matrix. 
Author Contributions: Conceptualization, F.G., C.M.M. and S.G.; formal analysis, C.M.M., S.G., S.P., F.M., M.A. and F.G.; investigation, C.M.M., S.G., S.P. and F.M.; data curation, F.G.; writing-original draft preparation, C.M.M., S.G., F.M., M.A. and F.G.; writing-review and editing, C.M.M., S.G. and F.G.; supervision, F.G. All authors have read and agreed to the published version of the manuscript.

Funding: This research received no external funding.

Institutional Review Board Statement: Not applicable.

Informed Consent Statement: Not applicable.

Data Availability Statement: Not applicable.

Conflicts of Interest: The authors declare no conflict of interest.

\section{References}

1. Oyebode, O.; Gordon-Dseagu, V.; Walker, A.; Mindell, J.S. Fruit and vegetable consumption and all-cause, cancer and CVD mortality: Analysis of Health Survey for England data. J. Epidemiol. Community Health 2014, 68, 856-862. [CrossRef] [PubMed]

2. Nooyens, A.C.; Bueno-de-Mesquita, H.B.; van Boxtel, M.P.; van Gelder, B.M.; Verhagen, H.; Verschuren, W.M. Fruit and vegetable intake and cognitive decline in middle-aged men and women: The Doetinchem Cohort Study. Br. J. Nutr. 2011, 106, 752-761. [CrossRef] [PubMed]

3. Sanchez-Villegas, A.; Henriquez-Sanchez, P.; Ruiz-Canela, M.; Lahortiga, F.; Molero, P.; Toledo, E.; Martinez-Gonzalez, M.A. A longitudinal analysis of diet quality scores and the risk of incident depression in the SUN Project. BMC Med. 2015, 13, 197. [CrossRef] [PubMed]

4. Huang, P.; O’Keeffe, M.; Elia, C.; Karamanos, A.; Goff, L.M.; Maynard, M.; Cruickshank, J.K.; Harding, S. Fruit and vegetable consumption and mental health across adolescence: Evidence from a diverse urban British cohort study. Int. J. Behav. Nutr. Phys. Act. 2019, 16, 19. [CrossRef] [PubMed]

5. Conner, T.S.; Brookie, K.L.; Richardson, A.C.; Polak, M.A. On carrots and curiosity: Eating fruit and vegetables is associated with greater flourishing in daily life. Br. J. Health Psychol. 2015, 20, 413-427. [CrossRef] [PubMed]

6. Conner, T.S.; Brookie, K.L.; Carr, A.C.; Mainvil, L.A.; Vissers, M.C.M. Let them eat fruit! The effect of fruit and vegetable consumption on psychological well-being in young adults: A randomized controlled trial. PLoS ONE 2017, 12, e0171206. [CrossRef]

7. Carr, A.C.; Bozonet, S.M.; Pullar, J.M.; Vissers, M.C. Mood improvement in young adult males following supplementation with gold kiwifruit, a high-vitamin C food. J. Nutr. Sci. 2013, 2, e24. [CrossRef]

8. Alharbi, M.H.; Lamport, D.J.; Dodd, G.F.; Saunders, C.; Harkness, L.; Butler, L.T.; Spencer, J.P.E. Flavonoid-rich orange juice is associated with acute improvements in cognitive function in healthy middle-aged males. Eur. J. Nutr. 2016, 55, 2021-2029. [CrossRef]

9. Casedas, G.; Les, F.; Gomez-Serranillos, M.P.; Smith, C.; Lopez, V. Bioactive and functional properties of sour cherry juice (Prunus cerasus). Food Funct. 2016, 7, 4675-4682. [CrossRef]

10. Muzammil, M.; Satish, S.; Praveenkumar, C.; Salyan, T.; Shabaraya, A. A study on anti-depressant activity of fresh fruit juice of actinidia deliciosa in experimental mice. Int. J. Pharma Chem. Res. 2019, 5, 5.

11. Tipton, K.F. 90 years of monoamine oxidase: Some progress and some confusion. J. Neural. Transm. 2018, 125, 1519-1551. [CrossRef]

12. Youdim, M.B.; Edmondson, D.; Tipton, K.F. The therapeutic potential of monoamine oxidase inhibitors. Nat. Rev. Neurosci. 2006, 7, 295-309. [CrossRef] [PubMed]

13. Saura, J.; Andres, N.; Andrade, C.; Ojuel, J.; Eriksson, K.; Mahy, N. Biphasic and region-specific MAO-B response to aging in normal human brain. Neurobiol. Aging 1997, 18, 497-507. [CrossRef]

14. Ramsay, R.R.; Albreht, A. Kinetics, mechanism, and inhibition of monoamine oxidase. J. Neural. Transm. 2018, 125, 1659-1683 [CrossRef] [PubMed]

15. Shih, J.C.; Chen, K.; Ridd, M.J. Monoamine oxidase: From genes to behavior. Annu. Rev. Neurosci. 1999, 22, 197-217. [CrossRef]

16. Mazzio, E.; Deiab, S.; Park, K.; Soliman, K.F. High throughput screening to identify natural human monoamine oxidase B inhibitors. Phytother. Res. 2013, 27, 818-828. [CrossRef]

17. Carradori, S.; D'Ascenzio, M.; Chimenti, P.; Secci, D.; Bolasco, A. Selective MAO-B inhibitors: A lesson from natural products. Mol. Divers. 2014, 18, 219-243. [CrossRef]

18. Dhiman, P.; Malik, N.; Sobarzo-Sanchez, E.; Uriarte, E.; Khatkar, A. Quercetin and Related Chromenone Derivatives as Monoamine Oxidase Inhibitors: Targeting Neurological and Mental Disorders. Molecules 2019, 24, 418. [CrossRef]

19. Chimenti, F.; Cottiglia, F.; Bonsignore, L.; Casu, L.; Casu, M.; Floris, C.; Secci, D.; Bolasco, A.; Chimenti, P.; Granese, A. Quercetin as the active principle of hypericum $\mathrm{h}$ ircinum exerts a selective inhibitory activity against MAO-A: Extraction, Biological analysis, and computational study. J. Nat. Prod. 2006, 69, 945-949. [CrossRef]

20. Olsen, H.T.; Stafford, G.I.; van Staden, J.; Christensen, S.B.; Jager, A.K. Isolation of the MAO-inhibitor naringenin from Mentha aquatica L. J. Ethnopharmacol. 2008, 117, 500-502. [CrossRef] 
21. Hou, W.C.; Lin, R.D.; Chen, C.T.; Lee, M.H. Monoamine oxidase B (MAO-B) inhibition by active principles from Uncaria rhynchophylla. J. Ethnopharmacol. 2005, 100, 216-220. [CrossRef] [PubMed]

22. Sloley, B.D.; Urichuk, L.J.; Morley, P.; Durkin, J.; Shan, J.J.; Pang, P.K.T.; Coutts, R.T. Identification of kaempferol as a monoamine oxidase inhibitor and potential neuroprotectant in extracts of Ginkgo biloba leaves. J. Pharm. Pharmacol. 2000, 52, 451-459. [CrossRef] [PubMed]

23. Herraiz, T. Relative exposure to beta-carbolines norharman and harman from foods and tobacco smoke. Food Addit. Contam. 2004, 21, 1041-1050. [CrossRef] [PubMed]

24. Herraiz, T.; Chaparro, C. Human monoamine oxidase enzyme inhibition by coffee and beta-carbolines norharman and harman isolated from coffee. Life Sci. 2006, 78, 795-802. [CrossRef]

25. Lee, S.A.; Hong, S.S.; Han, X.H.; Hwang, J.S.; Oh, G.J.; Lee, K.S.; Lee, M.K.; Hwang, B.Y.; Ro, J.S. Piperine from the fruits of Piper longum with inhibitory effect on monoamine oxidase and antidepressant-like activity. Chem. Pharm. Bull. 2005, 53, 832-835. [CrossRef]

26. Dreiseitel, A.; Korte, G.; Schreier, P.; Oehme, A.; Locher, S.; Domani, M.; Hajak, G.; Sand, P.G. Berry anthocyanins and their aglycons inhibit monoamine oxidases A and B. Pharmacol. Res. 2009, 59, 306-311. [CrossRef]

27. Bradford, M.M. A rapid and sensitive method for the quantitation of microgram quantities of protein utilizing the principle of protein-dye binding. Anal. Biochem. 1976, 72, 248-254. [CrossRef]

28. Commisso, M.; Negri, S.; Bianconi, M.; Gambini, S.; Avesani, S.; Ceoldo, S.; Avesani, L.; Guzzo, F. Untargeted and Targeted Metabolomics and Tryptophan Decarboxylase In Vivo Characterization Provide Novel Insight on the Development of Kiwifruits (Actinidia deliciosa). Int. J. Mol. Sci. 2019, 20, 897. [CrossRef]

29. Toffali, K.; Ceoldo, S.; Stocchero, M.; Levi, M.; Guzzo, F. Carrot-specific features of the phenylpropanoid pathway identified by feeding cultured cells with defined intermediates. Plant Sci. 2013, 209, 81-92. [CrossRef]

30. Chalabi, M.; Khademi, F.; Yarani, R.; Mostafaie, A. Proteolytic activities of kiwifruit actinidin (Actinidia deliciosa cv. Hayward) on different fibrous and globular proteins: A comparative study of actinidin with papain. Appl. Biochem. Biotechnol. 2014, 172, 4025-4037. [CrossRef]

31. Durak-Dados, A.; Michalski, M.; Osek, J. Histamine and Other Biogenic Amines in Food. J. Vet. Res. 2020, 64, 281-288. [CrossRef]

32. Sánchez-Pérez, S.; Comas-Basté, O.; Rabell-González, J.; Veciana-Nogués, M.T.; Latorre-Moratalla, M.L.; Vidal-Carou, M.C. Biogenic Amines in Plant-Origin Foods: Are they Frequently Underestimated in Low-Histamine Diets? Foods $2018,7,205$. [CrossRef]

33. Butnariu, M.; Butu, A. Chemical composition of Vegetables and their products. Handb. Food Chem. 2015, 1, 627-692. [CrossRef]

34. Pott, D.M.; Osorio, S.; Vallarino, J.G. From Central to Specialized Metabolism: An Overview of Some Secondary Compounds Derived from the Primary Metabolism for Their Role in Conferring Nutritional and Organoleptic Characteristics to Fruit. Front. Plant Sci. 2019, 10, 835. [CrossRef] [PubMed]

35. Tan, X.; Li, K.; Wang, Z.; Zhu, K.; Tan, X.; Cao, J. A Review of Plant Vacuoles: Formation, Located Proteins, and Functions. Plants 2019, 8, 327. [CrossRef] [PubMed]

36. Etienne, A.; Genard, M.; Lobit, P.; Mbeguie, A.M.D.; Bugaud, C. What controls fleshy fruit acidity? A review of malate and citrate accumulation in fruit cells. J. Exp. Bot. 2013, 64, 1451-1469. [CrossRef]

37. Mei, Y.; Pan, D.; Jiang, Y.; Zhang, W.; Yao, X.; Dai, Y.; Yu, Y.; Yao, X. Target discovery of chlorogenic acid derivatives from the flower buds of Lonicera macranthoides and their MAO B inhibitory mechanism. Fitoterapia 2019, 134, 297-304. [CrossRef] [PubMed]

38. Liu, L.; Liu, Y.; Zhao, J.; Xing, X.; Zhang, C.; Meng, H. Neuroprotective Effects of D-(-)-Quinic Acid on Aluminum ChlorideInduced Dementia in Rats. Evid. Based Complement. Alternat. Med. 2020, 2020, 5602597. [CrossRef]

39. He, Y.; Wang, Y.; Zhang, X.; Zheng, Z.; Liu, S.; Xing, J.; Liu, Z.; Zhou, H. Chemical characterization of small-molecule inhibitors of monoamine oxidase B synthesized from the Acanthopanax senticosus root with affinity ultrafiltration mass spectrometry. Rapid Commun. Mass Spectrom. 2020, 34, e8694. [CrossRef]

40. Andrade, J.M.; Biegelmeyer, R.; Dresch, R.R.; Maurmann, N.; Pranke, P.; Henriques, A.T. In vitro Antioxidant and Enzymatic Approaches to Evaluate Neuroprotector Potential of Blechnum Extracts without Cytotoxicity to Human Stem Cells. Pharmacogn. Mag. 2016, 12, 171-177. [CrossRef]

41. Clifford, M.N.; Jaganath, I.B.; Ludwig, I.A.; Crozier, A. Chlorogenic acids and the acyl-quinic acids: Discovery, biosynthesis, bioavailability and bioactivity. Nat. Prod. Rep. 2017, 34, 1391-1421. [CrossRef] [PubMed]

42. Flores, P.; Hellin, P.; Fenoll, J. Determination of organic acids in fruits and vegetables by liquid chromatography with tandem-mass spectrometry. Food Chem. 2012, 132, 1049-1054. [CrossRef]

43. Denev, P.; Kratchanova, M.; Petrova, I.; Klisurova, D.; Georgiev, Y.; Ognyanov, M.; Yanakieva, I. Black Chokeberry (Aronia melanocarpa (Michx.) Elliot) Fruits and Functional Drinks Differ Significantly in Their Chemical Composition and Antioxidant Activity. J. Chem. 2018, 2018, 1-11. [CrossRef]

44. Batista-Silva, W.; Nascimento, V.L.; Medeiros, D.B.; Nunes-Nesi, A.; Ribeiro, D.M.; Zsogon, A.; Araujo, W.L. Modifications in Organic Acid Profiles During Fruit Development and Ripening: Correlation or Causation? Front. Plant Sci. 2018, 9, 1689. [CrossRef] [PubMed]

45. Dawidowicz, A.L.; Typek, R. Transformation of chlorogenic acids during the coffee beans roasting process. Eur. Food Res. Technol. 2017, 243, 379-390. [CrossRef] 
46. Guertin, K.A.; Loftfield, E.; Boca, S.M.; Sampson, J.N.; Moore, S.C.; Xiao, Q.; Huang, W.Y.; Xiong, X.Q.; Freedman, N.D.; Cross, A.J.; et al. Serum biomarkers of habitual coffee consumption may provide insight into the mechanism underlying the association between coffee consumption and colorectal cancer. Am. J. Clin. Nutr. 2015, 101, 1000-1011. [CrossRef]

47. Hagl, S.; Deusser, H.; Soyalan, B.; Janzowski, C.; Will, F.; Dietrich, H.; Albert, F.W.; Rohner, S.; Richling, E. Colonic availability of polyphenols and D-(-)-quinic acid after apple smoothie consumption. Mol. Nutr. Food Res. 2011, 55, 368-377. [CrossRef]

48. Lintas, C.; Adorisio, S.; Cappelloni, M.; Monastra, E. Composition and Nutritional-Evaluation of Kiwifruit Grown in Italy. N. Zealand J. Crop. Hortic. Sci. 1991, 19, 341-344. [CrossRef]

49. Martinez Pomier, K.; Ahmed, R.; Melacini, G. Catechins as Tools to Understand the Molecular Basis of Neurodegeneration. Molecules 2020, 25, 3571. [CrossRef]

50. Giacomeli, R.; Izoton, J.C.; Dos Santos, R.B.; Boeira, S.P.; Jesse, C.R.; Haas, S.E. Neuroprotective effects of curcumin lipid-core nanocapsules in a model Alzheimer's disease induced by beta-amyloid 1-42 peptide in aged female mice. Brain Res. 2019, 1721, 146325. [CrossRef]

51. Larit, F.; Elokely, K.M.; Chaurasiya, N.D.; Benyahia, S.; Nael, M.A.; Leon, F.; Abu-Darwish, M.S.; Efferth, T.; Wang, Y.H.; Belouahem-Abed, D.; et al. Inhibition of human monoamine oxidase A and B by flavonoids isolated from two Algerian medicinal plants. Phytomedicine 2018, 40, 27-36. [CrossRef] [PubMed]

52. Samoylenko, V.; Rahman, M.M.; Tekwani, B.L.; Tripathi, L.M.; Wang, Y.H.; Khan, S.I.; Khan, I.A.; Miller, L.S.; Joshi, V.C.; Muhammad, I. Banisteriopsis caapi, a unique combination of MAO inhibitory and antioxidative constituents for the activities relevant to neurodegenerative disorders and Parkinson's disease. J. Ethnopharmacol. 2010, 127, 357-367. [CrossRef] [PubMed]

53. Liu, R.H. Potential synergy of phytochemicals in cancer prevention: Mechanism of action. J. Nutr. 2004, 134, 3479S-3485S. [CrossRef] [PubMed] 